\title{
Pre-Service Science Teachers' Skills in Applying Guided Inquiry, Modified Inquiry, and Open inquiry in Micro- teaching Course
}

\author{
Parmin $^{1}$, Arief Muttaqiin ${ }^{2}$ \\ ${ }^{1}$ UniversitasNegeri Semarang \\ ${ }^{2}$ UniversitasNegeriPadang \\ *parmin@mail.unnes.ac.id
}

\begin{abstract}
The study aimed to measure the skills of pre-service science teachers in applying three inquiry models in the microteaching course. The study was conducted on 56 pre-service science teachers who joined the microteaching course. A comparative study method was adopted by comparing the research target skills in applying three different inquiry learning models. The results revealed that the pre-service science teachers scored 84 for the guided inquiry or categorised as 'very good', 79 for the modified inquiry or in a 'good' category, and 75 for the open inquiry or belonged to the 'good' category. A correlation coefficient analysis showed that the $r_{\text {count }}$ was 0.620 while the $r_{\text {table }}$ with a significant level of $5 \%$ for $\mathrm{N}=56$ and $\mathrm{df}=\mathrm{N}-2=56-2=54$ was 0.354 . Thus, the $\mathrm{r}_{\text {count }}>\mathrm{r}_{\text {table }}$ or $0.620>0.354$ and Ha was accepted. The results indicated that there was a significant correlation between pre-service science teachers' skills in applying three different inquiry models. Therefore, it concluded that the pre-service science teachers achieved the highest score when applying the guided inquiry yet remained to get good scores when implementing the modified and open inquiry model.
\end{abstract}

Keywords: pre-service teachers, science, inquiry,microteaching

\section{Introduction}

Micro-teaching is one of the essential courses for pre-service science teachers. In the class, the students would learn various learning models including the inquiry model. However, a student has to pass other courses like science learning strategies, science learning evaluation, and curriculum development as the requirement for taking the micro-teaching session. The three prerequisite courses have provided experience in studying learning theories followed by preparing learning devices and evaluation instruments. The inquiry model becomes the dominant learning model chosen in science learning for its orientation in analytical and critical thinking of the students. Moreover, the inquiry is suitable for science learning as practical activities mostly follow it. Other than that, inquiry-based science learning provides opportunities for each student to develop their potential [1-3].

A preliminary analysis was performed on the achievements of microteaching learning in 2017 at the Integrated Sciences Education Program, Universitas Negeri Semarang. There were 42 students joined the lecture, and 23 of them selected the guided inquiry as for their 
model. It revealed that the average score of the 42 students was 87 . This score was good, yet some problems arose during their teaching demonstration. Some of the topics the future teachers chose did not match with the guided inquiry while there are some other kinds of inquiry such as the modified inquiry and open inquiry which may be better when applied to the learning activities. This mismatch resulted in the less-developed potentials owned by the students (in this case is their classmates acting as students). Frequently, the future teachers ended up guiding all the stages of inquiry and not giving the students chances to participate.

An initial study was also conducted to the future science teachers of Integrated Sciences Education Program, Faculty of Mathematics and Natural Sciences, Universitas Negeri Padang (UNP) on the Academic Writing course. The study found out that most future teachers had the inquiry as for the most-selected model for their field training program. The reason underlying this current selection was the prospective teachers' understanding that science could not be separated from concept discovery and implementation. UNP's preliminary research was limited to observation as the micro-teaching course left several meetings to go. Therefore, the numerical data were collected in Universitas Negeri Semarang as the future students have finished joining the class.

To the extent to the performed analysis, a measurement on the future teachers' ability in implementing the inquiry model was done through the 2018 Teacher Training Program held in three partner schools; SMP Negeri 13, SMP Negeri 32, and SMP Islam Al Azhar 29. The data of future teachers' teaching practice were obtained from classroom observation, and it turned out that they applied only the guided inquiry for all topics. There were chances for them to adopt the modified even the open inquiry in their teaching process. The applied guided inquiry could not be declared successful as the students remained to depend on the teacher in discovering science concepts. Other than that, the teachers provided non-contextual problems so that the students were less interested in solving problems.

Students' inquiry skill is shaped when they are discovering problems in society. Thus, inquiry learning does not need firm boundaries as the students have to be independent in solving science problems [4-6]. Inquiry-based learning gave opportunities to conceptual building and implementation through scientific studies; furthermore, it requires teachers' favourable skill in planning and implementation. In addition to providing chances, inquiry model facilitates the students to use their personal learning style as well as design the discovery process [7-11]. Therefore, it will train the students' learning independence.

This research intended to measure the pre-service science teachers' skills in performing inquiry models during the Micro-teaching course. Videos about the implementation of three learning models. Assessment through observation was performed to the learning tools and teaching practice particularly to the accuracy of the model and learning activities. Not only the lecturer did the observation but also the peers. The assessment is crucially done to prepare the pre-science teachers before joining the Teacher Training Program.

\section{Methods}

This study adopted the comparative method referring to [12] by comparing the preservice science teachers' skill in applying the three inquiry models. The research target was 56 science education students joining the micro-teaching course. All of the science education students have passed the pre-requisite courses consisting of Science Learning Strategies, Science Learning Evaluation, and Curriculum Development. The science education students 
must get through the micro-teaching session as one of the requirement to join the Teacher Training Program.

Every science education student compiled three learning tools for 40 minute-learning each. Prior to learning tool arrangement, short videos about three types of inquiry models were displayed as their reference and inspiration. Later, the science education students were required to implement all the three kinds of inquiry, the guided inquiry in the first learning, the modified inquiry in the second learning, and the open inquiry in the third learning. Admittedly, the topic being discussed has to be carefully picked so that it is suitable for the kind of inquiry. Furthermore, each learning tool was assessed by the lecturer who was also the author.

The instruments employed included assessment rubric for a learning tool and microteaching performance. The Likert scale were referred having the following categories; $4=$ very good, $3=$ good, $2=$ low, $1=$ very low. The assessment indicators for learning tool were: (1) clarity of indicator formulation; (2) suitability of learning activities and model syntaxes; (3) suitability of the media and learning materials; (4) assessment appropriateness. Moreover, the micro-teaching performance assessment indicators included: (1) skill in opening the lesson; (2) skill in applying the syntax of inquiry model; (3) skill in closing the lesson.

This study is limited to measure the skills in applying the three inquiry models. The syntaxes of inquiry are orientation, problem formulation, hypotheses formulation, data collection, hypotheses examination, and conclusion arrangement. However, the three inquiry models differ from one another in terms of supervision frequency between teachers and students. In the guided inquiry, the teachers guide the students thoroughly in applying the inquiry syntaxes while the teachers give opportunities to the students to strive for completing the syntaxes. On the other hand, the teachers only provide direction for the students to perform all the activities needed in accomplishing the syntaxes independently.

The data were analysed descriptive-quantitatively to measure future teachers' skill in applying three inquiry types. Further, a coefficient correlation analysis was carried out to know the $r_{\text {count }}$ to be compared with the $r_{\text {table }}$ for $5 \%$ significance level. If the $t_{\text {count }}>t_{\text {table }}$, a significant correlation of the future students' skill in implementing three various inquiry types.

\section{Results and Discussion}

The average classroom assessment of the learning tools compiled by 56 pre-service science teachers are presented in Table 1

Table 1. The learning tool assessment results (Classroom Average)

\begin{tabular}{lccc}
\multicolumn{1}{c}{ Indicator } & GuidedInquiry & Modified Inquiry & Open Inquiry \\
\hline $\begin{array}{l}\text { Clarity of indicator } \\
\text { formulation }\end{array}$ & 3,43 & 3,46 & 3,38 \\
$\begin{array}{l}\text { Suitability of learning } \\
\text { activities and model }\end{array}$ & 3,36 & 3,16 & 2,91 \\
$\begin{array}{l}\text { syntaxes } \\
\begin{array}{l}\text { Suitability of the media and } \\
\text { learning materials }\end{array}\end{array}$ & & & \\
Assessment appropriateness & 3,32 & 3,34 & 3,30 \\
\hline Average & 3,30 & 3,30 & 3,16 \\
\hline Category & 3,35 & 3,32 & 3,19 \\
\hline
\end{tabular}


Based on Table 1, there was a decrease in the score of guided, modified, and open inquiry. The best score was on the guided inquiry yet all was in a good category. These results came up since the future teachers were more familiar with the guided inquiry, the topselected one, than the other two kinds.

Furthermore, assessment on the micro-teaching performance was done by either the lecturer or peers. The assessment results are shown in Table 2.

Table 2. The Assessment Results of the Micro-teaching Performance (Classroom Average)

\begin{tabular}{lccc}
\hline \multicolumn{1}{c}{ Indicator } & Guide Inquiry & Modified Inquiry & Open Inquiry \\
\hline $\begin{array}{l}\text { Skill in opening the lesson } \\
\text { Skill in applying the syntax }\end{array}$ & 3,50 & 3,20 & 3,14 \\
of inquiry model & 3,38 & 3,14 & 3,00 \\
Skill in closing the lesson & 3,46 & 3,16 & 3,16 \\
\hline Average & 3,45 & 3,17 & 3,10 \\
\hline Category & Good & Good & Good \\
\hline
\end{tabular}

The assessment results indicated that generally the 56 future science teachers gained scores $>3$ and categorised as good. However, seen from Table 2, the higher the inquiry level, the lower the score. This means that the future teachers remained to find obstacles in implementing the higher inquiry level though they were in a good category. In the guided inquiry, the future teachers supervised the students from the beginning (orientation) until the end (conclusion arrangement). In other words, future teachers did not give the students many chances for independent activities.

When converted to score ranging from 0-100, the pre-service science teachers' value in applying the guided inquiry model was 84,79 for the modified inquiry, and 75 for the open inquiry. The preparation given to the future teachers at the beginning of the micro-teaching course has been sufficient enough for them to understand the types of inquiry model. This in line with [13] who argued that video analysis could help a teacher in preparing classroom learning.

After converting the performance scores, a coefficient correlation analysis to compare the science education students' skill in the three levels of inquiry. The analysis results found that the rcount was 0,620 while the rtable was 0,354 at the $5 \%$ of significance level for $\mathrm{N}=56$ and $\mathrm{df}=\mathrm{N}-2=56-2=54$. Thus, the $\mathrm{r}_{\text {count }}>\mathrm{r}_{\text {table }}$ or $0,620>0,354$ meaning that there was a significant correlation between the science education students' skill in the three inquiry stages. The correlation analysis outcome has strengthened the data obtained during the research which indicated that the pre-service science teachers have had understood the three type of inquiry model and their implementation. However, this research did not calculate precisely the effect of preparation to the science education students' skill in each inquiry stage.

The inquiry syntaxes implementation has been systematically done starting from orientation, problem formulation, hypotheses formulation, data collection, hypotheses examination, and conclusion arrangement. An important note from this research was that the future teachers were more familiar with the level one by giving guidance to the students when conducting activities. Moreover, the observation of the micro-teaching performance highlighted that the future teachers tended to be dominant in advising while the students' independent discovery has not been optimally developed. The students' self-regulation and 
reduction in teachers' authority are the keys to successful inquiry learning [14]. Therefore, further training for future teachers was urgently done.

The inquiry is not the only science learning model yet the most-selected one. This study portrays the skills of applying inquiry models because they are most often used in science learning. Improvements need to be made in preparing pre-service science teachers so that they are more skilled in applying the learning model. According to the results of this study, the more intensive experience is needed for the pre-service science teachers to conduct learning observations and analyse various learning videos. A more tangible experience is required instead of just learning the model syntaxes theoretically.

\section{Conclusion}

This study concluded that pre-service science teachers' skill in implementing three inquiry types was good. The highest to the lowest score were respectively on the guided, modified, and open inquiry. Nevertheless, the teacher's domination during the learning process needs to be reduced, and advanced teacher training has to be done.

\section{References}

[1]Schramm JW, Jin H, and Keeling, EG 2018 Res. Sci. Educ.5 913.

[2] van Uum M S, Peeters M, andVerhoeff R P2019Res. Sci. Educ.1-28.

[3] Murphy C., Smith G,and Broderick N. 2019Res. Sci. Educ. 1

[4] Putra B, Prayitno A, and Maridi2018 J. Pendidikan IPA Indonesia4 476.

[5] LackovićN2018 Video J. Educ. Pedagogy11.

[6] KelpC 2018Synthese 1.

[7] Gyllenpalm2018 Cult. Stud. Sci. Educ.131.

[8] Hossain Z, Bumbacher E, Brauneis A, Diaz M, Saltarelli A, Blikstein P, and RiedelKruse, I H 2018Int. J. Artif. Intell.Educ.4, 478.

[9] Riordan R, andCaillier S 2019 Schools as Equitable Communities of Inquiry Schools as Equitable Communities of Inquiry. In: Cook J. (eds) Sustainability, Human WellBeing, and the Future of Education (Palgrave Macmillan, Cham).

[10] Amels J, Krüger M, Suhre C, and van Veen K. 2019 J. Educ. Change 1.

[11] Fitzgerald M, Danaia L, and McKinnon D H2017 Res. Sci. Educ.1.

[12] Muri Y 2014 MetodePenelitianKuantitatif, Kualitatif\&PenelitianGabungan (Jakarta: Prenadamedia Group).

[13] Higgins J, Moeed A, and Eden R. 2018 Asia-Pac. Sci. Educ.1 6.

[14] Parmin P, Sajidan S, Ashadi A, Sutikno S, and Fibriana F 2017 J. Pendidikan IPA Indonesia 2365. 